\title{
Tamamlayıcı Sağlık Sigortasının Sürdürülebilirliği: Öğretim Elemanlarının Görüşlerinin Değerlendirilmesi
}

\author{
Sustainability of Complementary Health Insurance: Evaluation of the Views \\ of Lecturers
}

\section{Öz}

$\mathrm{Bu}$ çalı̧̧manın amacl, öğretim elemanlarının tamamlayıcı sağllk sigortasının sürdürülebilirliği hakkındaki görüşlerini belirlemek ve sosyodemografik özellikleri ile tamamlayıcı sağlık sigortasının sürdürülebilirliği konusundaki görüşleri arasındaki ilişkiyi incelemektir. Bu kapsamda Karadeniz Teknik Üniversitesi'nde görev yapan ve araştırmaya gönüllü katılan toplam 420 öğretim elemanına yüz yüze anket uygulanmıştır. Araştırma verisi, kişisel bilgi formu ve tamamlayıcı sağhlk sigortası sürdürülebilirlik ölçeği aracilğ̆yla toplanmıs ve Anova ve t testlerinden yararlanılarak analiz edilmiştir. Tamamlayıcı sağlık sigortası sürdürülebilirlik ölçeği ortalama puanı $(2,83)$, öğretim elemanlarının tamamlayıcı sağhlk sigortasının sürdürülebilirliği konusunda tam bir karara varamadıklarını göstermektedir. Tamamlayıcı sağllk sigortasının sürdürülebilirlik düzeyi ile cinsiyet, medeni durum, bilim dalı ve aylık gelir düzeyi değişkenleri arasında \%5 düzeyinde anlaml bir ilişki olduğu belirlenmiştir. Araştırma sonucunda öğretim elemanlarının tamamlayıcı sağllk sigortasının sürdürülebilirliği konusuna bakış açılarının cinsiyet, medeni durum, bilim dalı ve gelir düzeyi faktörlerine göre değişkenlik gösterdiği tespit edilmiştir.

\section{Abstract}

The purpose of this study is to determine the views of the lecturers on the sustainability of complementary health insurance and to examine the relationship between socio-demographic characteristics and their views on the sustainability of complementary health insurance. In this context, a faceto-face questionnaire was applied to a total of 420 lecturers who work at Karadeniz Technical University and participated in the study voluntarily. Research data was collected through a personal information form and complementary health insurance sustainability scale and analyzed using Anova and $t$-tests. The mean score on the complementary health insurance sustainability scale (2.83) shows that the lecturers could not make a full decision on the sustainability of the complementary health insurance. It was determined that there is a significant relationship at the level of $5 \%$ between the sustainability level of complementary health insurance and the variables of gender, marital status, discipline and monthly income level. As a result of the research, It was determined that they have a more positive opinion about the sustainability of complementary health insurance males compared to females, single lecturers compared to married ones, lecturers working in the field of sciences compared to social sciences and those with low monthly income compared to those with higher monthly income.

\section{Giriș}

Türkiye' de genel sağlık sigortası kapsamında faydalanılan

\author{
Furkan Serdar \\ Arş. Gör., Ondokuz Mayıs Üniversitesi, \\ İktisadi ve İdari Bilimler Fakültesi \\ furkan.serdar@omu.edu.tr, \\ Orcid: 0000-0001-7643-1163
}

\section{Ahmet Kurtaran \\ Doç. Dr., Karadeniz Teknik Üniversitesi, İktisadi ve İdari Bilimler Fakültesi kurtaran@ktu.edu.tr, \\ Orcid: 0000-0003-1780-2491}

\section{Ayten Turan Kurtaran}

Doç. Dr., Karadeniz Teknik Üniversitesi, Sağlık Bilimleri Fakültesi, ayturan@ktu.edu.tr,

Orcid: 0000-0001-6116-6467

\section{Melike Kurtaran Çelik \\ Doç.Dr., Trabzon Üniversitesi, \\ TOMYO,melike@ktu.edu.tr, \\ Orcid: 0000-0002-4152-9459}

Article Type / Makale Türü

Research Article / Araştırma Makalesi

Anahtar Kelimeler

Tamamlayıcı Sağ lık Sigortası, Öğretim

Elemanı, Sürdürülebilirlik

\section{Keywords \\ Complementary Health Insurance, Lecturers, Sustainability}

\section{JEL Codes: G20, G22, G28}

Bilgilendirme

Bu çalı̧̧ma; Furkan Serdar'ın "Tamamlayıı sağllk sigortasının sürdürülebilirliği: Öğretim elemanları üzerine bir araştırma" adl yüksek lisans tezinden türetilmiştir

Submitted: $\quad 10 / 05 / 2021$ Accepted: $\quad 22$ / 05 / 2021 sağlık hizmetlerinin yeterli düzeyde memnuniyet oluşturmaması sağlık alanında bir değişikliğin yapılmasına neden olmuştur. Ortaya çıkan bu değişiklikler nedeniyle devletin beklentilerinin mevcut finansal kaynaklarla karşılanmaması sonucu bu sistem süreklilik noktasında birtakım sıkıntılar doğurmuştur. Bu sebeple sağlık alanında yapılmak istenilen farklılık ve değişiklikler 
sonucu Tamamlayıcı Sağlık Sigortası (TSS) modeli ortaya çıkmıştır. (Şahin, 2018: 30). Sosyal sağlık sigortası uygulamasını yürüten TSS, gerçekleşen bu finansal yükü kısmen de olsa üzerine almaktadır. TSS'nin sağlamış olduğu faydalar, kamu sağlık sigortasının kapsamından fazlaca etkilenmektedir. Geri ödeme oranları, ülkeden ülkeye ve ülkelerdeki çeşitli sigorta poliçelerinin sunmuş olduğu alternatiflere göre farklılık göstermektedir (Mossialos ve Thomson, 2004: 66). TSS özel sağlık sigortasının bir ürünüdür. Genel sağlık sigortası (GSS) teminat paketleri içerisine dahil olmayan veya teminat paketine dahil olup ancak kısmen karşılanan durumlarda kişinin cepten ödeme yapması gereken ya da daha üst standartlarda hizmet almak istediği durumlarda ortaya çıkan bir sigorta türüdür. Kısacası TSS, kurum tarafından kapsama alınmayan veya kapsama alındığı halde ek ücret ödemesi gereken sağlık hizmetlerinin bu sigorta aracılığıyla kapsam altına alınmasını ifade etmektedir. (Önder vd., 2016: 28). Bu sigortaya ilk kez 5510 sayılı Sosyal Sigortalar ve Genel Sağlık Sigortası Kanunu'nun 98.maddesinde değinilmiştir. Bu sigortanın tanımı, kapsamı ve uygulaması 28.06.2012 tarihli genelgede SGK tarafından ortaya koyulmuştur.

TSS'nin en önemli özelliklerinden biri yüksek oranda olan erişilebilirliktir. Katılım paylarının oldukça yüksek olması, düşük gelirli bireylerin sağlık hizmetine olan erişimini azaltmakta ve bunun sonucu olarak da sağlık hizmetleri eşit ve adil olmayan bir şekilde kullanılmaktadır. TSS'nin tanınırlık düzeyi arttıkça ve düşük gelirli bireylerin bu sigortayı satın alması kolaylaştıkça bu eşitsizlik gittikçe ortadan kalkmaktadır. Bu sigortanın bir başka önemli özelliği ise, sağlık hizmeti kullanımının artmasıdır. Tedavi ve ilaç masraflarının paylaşımı bireyleri (hastaları) maliyetler konusunda daha bilinçli yapacaktır. Fakat, eğer sigorta, masrafların bu kısmına uygulanırsa bireyler sağlık hizmetinin marjinal maliyetlerinin düştüğünü fark edecekler ve bunun sonucu olarak da daha fazla tüketeceklerdir. Ortaya çıkan bu ahlaki tehlike, artan sağlık hizmeti maliyetleriyle sona erecektir (Tajika ve Kikuchi, 2012: 129).

TSS, hem özel hizmet almak isteyen bireyler için daha az maliyetli bir sigorta olması hem kamudan oluşan maliyet açığını azaltıcı etkisi hem de özel sağlık kuruluşları için nefes anlamına geldiğinden tüm taraflarca pozitif karşılanmaktadır. Aynı zamanda özel sağlık sigortacılığında sigortalı kişi sayısı ve prim üretiminde de yüksek oranda artış gözlenmektedir. 2019 yılsonu itibariyle Türkiye'de TSS'ye sahip toplam 1 milyon 354 bin civarı sigortalı kişi mevcuttur. TSS kapsadığı hizmetler bakımından; yatarak tedavi, ayakta tedavi, hekim muayenesi, reçeteli ilaçların temini, fizik tedavi ve rehabilitasyon masrafları, doğum ek teminatı ve benzeri birçok sağlık hizmetini karşılamaktadır. TSS'ye sahip 1 milyon 354 bin civarı kişinin 1 milyon 70 bin civarı ayakta ve yatarak tedavi imkanlarından faydalanmaktadır. (TSB, 2019). Ancak, TSS'den yararlanan kişi sayısı istenilen düzeye ulaşmamıştır.

Türkiye' de TSS konusu ile ilgili yapılan çalışmaların sınırlı sayıda olduğu görülmektedir. Yapılan çalışmalarında çoğunlukla toplumdan rastgele seçilen örneklem grupları üzerinde yapıldığı gözlenmektedir. Bu çalışmada, bilgi ve eğitim düzeyi yüksek, toplumda önemli bir konuma sahip ögrretim elemanlarının sosyo-demografik özelliklerine göre TSS'nin sürdürülebilirliği konusundaki görüşlerinin değerlendirilmesi amaçlanmıştır.

\section{Literatür İncelemesi}

TSS uygulaması Türkiye'ye nazaran Avrupa' da çok daha önceleri kullanılmaktaydı. Kapsam ve ismi ülkeden ülkeye değişiklik gösterse de genel olarak "Tamamlayıcı Özel Sağlık Sigortası" adı altında sunulmaktadır. Genelde Avrupa'da daha yaygın olarak kullanilan TSS ile ilgili elde edilen yabancı literatüre bakıldığında TSS'nin mevcut durumu ve tercih edilme sebeplerini araştıran Bauer vd. (2019), Almanya'da bir sigorta şirketinden elde ettikleri 98.000'den fazla kişiye ait verileri kullanmıştır. Yapılan çalışma sonucunda, TSS'ye sahip olan bireylerin diğerlerine nazaran daha düşük risk grubunda oldukları sonucuna ulaşılmıştır. Bireyin TSS satın alma tercihi önünde ise üç temel faktör olduğu bunların da bireyin mesleği, yaşadığ edilmiştir. Bununla birlikte uzun dönemli bakım sigortası maliyetleri de TSS'nin tercih edilmesinde önemli bir faktörü oluşturduğu belirtilmiştir. Hollanda'daki tüketicilerin sigorta şirketi tercih ve seçimlerinde TSS'nin rolünü ortaya koymayı amaçlayan Holst vd. (2018), çalışmalarında toplam 2259 kişiye anket yöntemi uygulanmıştır. Çalışmalarının sonucunda, TSS'ye sahip bireylerin mevcut 
sigorta şirketlerini değiştirme oranı \%6 iken, TSS'ye sahip olmayan bireylerin mevcut sigorta şirketlerini değiştirme oranının \% 16 olduğu tespit edilmiştir. Dolayısıyla TSS'ye sahip bireyler kendi sigorta şirketlerine daha bağlı oldukları sonucuna ulaşılmıştır. Bunun nedeni ise, TSS'ye sahip bireylerin riskten ve başka bir sigorta şirketine geçme kararlarından kaçınmalarının yüksek olmasıdır. Benzer şekilde Kaplan vd. (2017) çalışmalarında, İsrail halkının TSS hakkındaki bakış açılarını, tercihlerini ve bilgilerini ölçmeyi amaçlamışlardır. Çalışmada yaklaşık 350 kişiye telefonla anket yöntemi uygulanmıştır. Yapılan anket sonucunda, halkın \%85'inin TSS'ye sahip olduğu tespit edilmiştir. Dolayısıyla halkın bilinçli ve rasyonel olarak bir tercihte bulunduğu sonucu ortaya çıkmıştır. Ancak bu sigortayı kullananların TSS'nin sağladığı faydalar hakkında pek fazla bilgi sahibi olmadığı sonucu da ortaya çıkmıştır.

TSS'ye sahip olan ve olmayan bireylerin cepten yaptıkları harcamalar ve sağlık hizmetleri kullanımları arasındaki farkları tespit etmeyi amaçlayan Rad vd. (2017) çalışmalarında, cepten yapılan sağlık harcamalarında TSS'ye sahip olma veya olmama durumu arasında bir farkın olmadığı tespit edilmiştir. Ancak TSS'ye sahip bireylerin hastanelerde uzman ziyaretleri ve diş hekimliği hizmetlerinde TSS'ye sahip olmayanlara nazaran yüksek bir skora sahip oldukları sonucuna da ulaşılmıştır. Konuya farklı bir bakış açısıyla yaklaşan Pierre ve Jusot (2017), Fransa' da işverenler tarafından zorunlu olarak tutulan TSS'nin etkilerini ele almışlardır. Fransa'da halkın yüksek kısmının tamamlayıcı özel sağlık sigortasına sahip olduğu ve 2016 yılından itibaren özel sektörde çalışan kesimlere zorunlu olarak yapıldığı ortaya koyulmuştur. Dolayısıyla bu sigorta sayesinde kapsam dişı kalanların oranı yıllar itibariyle düşme eğilimi göstermiştir. Yapılan niteliksel çalışma sonucunda, ilaç teminatında sağlanan faydalar ve doktor seçme konusunda özgürlükler TSS'nin Fransa'da başarılı bir şekilde yürütüldüğünü ortaya koymuştur.

Biro ve Hellowell, 2016 yılında yapmış oldukları çalışmada, İngiltere' de TSS talebini ve kamuözel sektör etkileşimlerini ele almışlardır. Çalışmada anket yöntemi kullanılarak vatandaşların sağlık kuruluşlarında TSS'ye bakış açıları incelenmiştir. Yapılan çalışma sonucunda, kamu hastanelerinde yaşanan bekleme sürelerinin uzun olması ve sunulan hizmet kalitesi açısından TSS'nin kullanımının arttığı ve mevcut durumun zamanla daha da artacağı sonucuna varılmıştır. Ülkedeki nüfusun artışı ile kamu hastanelerinde yaşanılan sıkıntılar vatandaşları TSS'ye yönlendirirken, bu sigorta için finansal iyileştirmeler yapılmadığı taktirde ise bu artışın pek fazla belirgin olmayacağ 1 da tespit edilmiştir.

TSS'nin çeşitli ülkelerdeki kullanım durumunu araştıran çalışmalara bakıldığında; Saliba ve Ventelou (2007), çalışmalarında Fransa'da TSS'nin durumunu ve satın alma kararının önündeki etkenleri ele almışlardır. Niteliksel yapılan bu çalışmada, risk seviyesi düşük olan bireylerin TSS'ye sahip olduğu, risk seviyesi yüksek olanların ise kamu sağlık sigortasını kullandıkları tespit edilmiştir. Bunun önünde yatan en temel nedenin ise, gelir düzeyi olduğu ortaya koyulmuştur. Fransa' da TSS'yi tercih etmeden en önemli faktör bireylerin gelir düzeyleridir. Oluşan bu durumun da kamusal anlamda eşitsizlikler yaratacağı endişesini doğurduğu belirtilmiştir. Costa ve Rovira (2005) çalışmalarında, İspanya'da TSS'nin mevcut durumunu ve satın alma nedenlerini ele almışlardır. Çalışmada, İspanya'da ulusal sağlık sistemi her ne kadar yaygın olarak kullanılsa da son yıllarda TSS'ye ilginin arttığı ortaya koyulmuştur. Bunun arkasındaki yatan en büyük sebepler arasında, ulusal sağlık sisteminin tekdüze hizmet sunması, vergilendirmenin yüksek olması ve yoğun talebe ayak uyduramaması olduğu görülmüştür. Ayrıca, daha iyi eğitimli bireylerin TSS'ye daha yatkın oldukları sonucuna da ulaşılmıştır. Bununla birlikte TSS'nin sağladığı öncelikler ve önceden sıra beklemeksizin hizmet sağlaması bu sigortanın tercih edilmesinde en önemli etkenlerin olduğu tespit edilmiştir. Stevens vd. (1998) çalışmalarında, Belçika'da TSS'nin durumunu ve artan rolünü ortaya koymuşlardır. Niteliksel olarak gerçekleşen bu çalışmada, Belçika' da sosyal güvenlik sisteminin kapsam ve ödenekler bakımından sinırlı olduğu ve bu sosyal güvensizliğe alternatif olarak ortaya çıkan TSS'nin önemi vurgulanmıştır. TSS'lerin sunduğu bazı avantajların (dayanışma temelli sigorta) özel sigortalarda olmadığı gözlenmiştir. Sonuç olarak bazı dezavantajlar barındırsa da TSS kapsamındaki kişi sayısının giderek arttığı ve ekonomik anlamda sağladığı bazı imkanlarla gelecekte çok daha yaygın bir hale geleceği belirlenmiştir. Benzer şekilde Valtonen vd. (2014) çalışmalarında, Finlandiya'da TSS'nin kullanımını araştırmışlardır. Çalışmada yaklaşık 650 kişiye 
anket yöntemi uygulanmıştır. Yürütülen anket sonucunda, yetişkin halkın \%22,7' sinin ve çocukların \%52'sinin TSS'ye sahip oldukları tespit edilmiştir. Halkın TSS alma sebebinin, daha hızlı erişim, daha geniş seçenek ve daha iyi kalite olduğu gözlemlenmiştir. Çocuklar ile ilgili en önemli faktörün ise, ebeveynlerinin eğitim seviyesi ile ilgili olduğu ortaya çıkmıştır.

Kang vd. (2009) yılında yapmış olduğu çalışmada, Kore'de TSS'ye sahip kişilerin TSS'ye sahip olmayanlara göre doktora gitme sıklığını ölçmüşlerdir. Araştırmada 11.043 kişiye anket yöntemi uygulanmıştır. Anket sonuçları ve kıyaslamalar için probit model kullanılmıştır. Yapılan çalışma sonucunda; TSS'ye sahip kişilerin bu sigortaya sahip olmayanlara göre \%14 daha fazla doktor ziyareti gerçekleştirdiği tespit edilmiştir. Sonuç olarak Korelilerin tıbbi masrafları karşılamada TSS'ye güvendikleri ortaya çıkmıştır.

TSS' nin Türkiye' de yapılmış çalışmalarına bakıldı ğında erişebilecek kaynakların nispeten sınırlı oldukları gözlenmiştir. 1990'lı yıllardan başlayarak konuşulmaya başlayan bu uygulama Sosyal Güvenlik Kurumu (SGK)'nun 2012 yılında yayımlamış olduğu genelge ile yasal olarak tanınır hale gelmiştir. TSS satın alan kişilerin TSS hakkındaki bilgi ve görüşlerini değerlendiren Bitimli (2019), yapmış olduğu çalışmada TSS'ye sahip toplam 261 kişiye anket çalışması uygulanmıştır. Yapılan anket çalışması sonucunda, TSS'ye sahip kişilerin yaşları ile medeni durumlarının ürünü satın alma memnuniyetleri arasında anlamlı bir ilişkinin olduğu tespit edilmiştir. Sonuç olarak, sektörde TSS hakkında genel olarak olumsuz bir düşüncenin bulunmadığ 1 ve bu sebeple satın alma faaliyetlerinin sürdürülebileceği pazar imkanının olduğu sonucuna varılmıştır. Cihangiroğlu (2019), çalışmasında TSS'yi ele alıp Türkiye için bu modele neden ihtiyaç duyulduğuna yönelik bir araştırma ortaya koymuştur. Sağlık hizmet sunucuları ve sigorta şirketleri açısından TSS'nin önemi vurgulanarak MEDULA sistemi detaylıca açıklanmıştır. Araştırmanın sonucunda ise, TSS'nin uygulama alanını genişletmek için bu sigorta adına tanıtıcı faaliyetlerin yapılması, alternatif ürünlerin ortaya koyulması ve MEDULA sistemiyle veri paylaşımını sağlayacak sistem alt yapısının geliştirilmesi yönünde önerilerde bulunulmuştur.

Genel Sağlık Sigortasına sahip kişilerin TSS'ye dair bilgi sahibi olma durumlarını tespit etmeyi amaçlayan diğer çalışmalardan Şahin (2018), toplam 123 kişiye anket çalışması uygulanmıştır. Yapılan anket çalışması sonucunda, ankete katılan 123 kişinin TSS'yi duymuş oldukları ancak detaylı bir bilgiye sahip olmadıkları ve bu yüzden TSS yaptırmayı düşünmedikleri ortaya çıkmıştır. Bu kişilerin, TSS'yi yaptırmayı düşünmemelerinin nedeni ise; sigorta şirketlerinin ilgili teminat hakkında yeterli bilgiyi ulaştıramamış olmalarından kaynaklandığı sonucuna varılmıştır. Buna benzer şekilde Önder vd. (2016), Nevşehir'de özel bir hastaneye başvuran hastaların TSS'den ne kadar haberdar olduklarını tespit etmeyi amaçlamıştır. Çalışma sonucunda, bireylerin TSS'den yeterince haberdar olmadıkları ortaya çıkmıştır. Bu sigortaya sahip olanların ise memnuniyet düzeylerinin genel olarak iyi olduğu sonucuna varılmıştır. Ancak sonuç olarak, her ne kadar TSS' nin sunduğu hizmetlerden genel olarak memnun olunsa da bu uygulamanın yaygınlaşması için çok daha fazla tanıtım ve bilgilendirmeye ihtiyacının olduğu gözlemlenmiştir.

Yukarıda bahsedilen çalışmalardan farklı olarak genel sağlık sigortası sisteminin sürdürülebilirliği için TSS'nin gerekliliğini inceleyen Tapan vd. (2015), Türkiye Sigorta ve Reasürans Şirketler Birliğgi' ne kayıtlı 15 sağlık sigorta şirketinde görev alan sağlık sigortacılarına anket çalışması uygulanmıştır. Çalışma sonucunda, katılımcıların \%74'ü genel sağlık sigortası sisteminin mevcut hali ile topluma eşit ve kaliteli sağlık hizmeti sunabilmek adına sürdürülebilir bir sistem olmayacağ1 görüşünü beyan etmişlerdir. Bunun birlikte katılımcıların \%93'ünün de genel sağlık sigortasının sürdürülebilirliği için TSS bileşeni ile birlikte sunulması gerektiği sonucuna varmışlardır. Orhan ve Kıyak (2015) yapmış oldukları çalışmada, Türkiye'de özel sağlık kuruluşlarında TSS'nin nasıl işlediği, faydalarının ne olduğu, ne gibi sorunları ve zararları olabileceğini tespit etmeyi amaçlamışlardır. Çalışmada, 5 sigorta şirketinin üst düzey yöneticileri ile bireysel derinlemesine görüşme yapılarak veri elde edilmiştir. Yapılan çalışma sonucunda, yöneticilerin genel olarak, TSS'nin sağlığa ulaşımı kolaylaştıran, özel sağlık kurumlarında hiçbir fark ücreti ödemeden sağlık hizmetleri almaya olanak sağlayan yararlı bir sigorta türü olduğunu beyan etmişlerdir. Bununla birlikte, TSS'nin sosyal güvenlik kurumunun zaman içinde yapmış olduğu veya yapacağı yenilikler ile gelişme göstereceği sonucuna varılmıştır. 
Değer vd. (2013) çalışmalarında, TSS'nin Türkiye' deki önemini ve potansiyelini ortaya koymayı amaçlamışlardır. SGK, OECD yayınları ve Türkiye Sigorta Birliği'nin veri tabanı incelenerek elde edilen veriler sonucunda, özel hastane sayısının son 5 yılda \%50 arttığı ve dolayısıyla TSS'nin da pazar payının arttığı tespit edilmiştir. 2012 yılına kadar Türkiye' de 2 milyon özel sağlık sigortalı kişinin olduğu ve gelecek yıllarda TSS'nin da etkisiyle bu sayının daha da çok katlanacağ1 belirtilmiştir. Kısacası araştırmacılar finansal açıdan sürdürülebilir bir sağlık sistemi için TSS'nin bir alternatif olacağı görüşünü önermişlerdir.

\section{Araştırmanın Metodolojisi}

Bu kısımda araştırmanın amacı, araştırma hipotezleri, araştırma evreni ve örneklemi, veri toplama aracı ve uygulanan istatistiksel analiz yöntemleri ile ilgili bilgiler sunulmuştur.

\subsection{Araștırmanın Amacı}

Araştırmada, Karadeniz Teknik Üniversitesi'ndeki öğretim elemanlarının TSS'nin sürdürülebilirliği ile ilgili görüşlerinin sosyo-demografik değişkenlere göre incelenmesi amaçlanmiştır.

Bu amaçla “TSS'nin sürdürülebilirliği açısından öğretim elemanları arasında sosyo-demografik değişkenler bakımından fark var mıdır?" sorusunun cevabı araştırılmak istenmiştir. Bu kapsamda oluşturulan hipotezler aşağıdaki gibidir.

$\mathrm{H}_{1}$ : TSS'nin sürdürülebilirliği açısından öğretim elemanları arasında cinsiyet bakımından fark vardir.

$\mathrm{H}_{2}$ : TSS'nin sürdürülebilirliği açısından öğretim elemanları arasında yaş bakımından fark vardır.

$\mathrm{H}_{3}$ : TSS'nin sürdürülebilirliği açısından öğretim elemanları arasında medeni durum bakımından fark vardir.

$\mathrm{H}_{4}$ : TSS'nin sürdürülebilirliği açısından öğretim elemanları arasında çocuk sayısı bakımından fark vardir.

$\mathrm{H}_{5}$ : TSS'nin sürdürülebilirliği açısından öğretim elemanları arasında akademik unvan bakımından fark vardır.

$\mathrm{H}_{6}$ : TSS'nin sürdürülebilirliği açısından öğretim elemanları arasında bilim dalları bakımından fark vardır.

$\mathrm{H}_{7}$ : TSS'nin sürdürülebilirliği açısından öğretim elemanları arasında aylık gelir düzeyi bakımından fark vardır.

\subsection{Araştırma Evreni ve Örneklemi}

Araştırmanın evrenini Trabzon ilinde bulunan Karadeniz Teknik Üniversitesi'nde çalışmakta olan öğretim elemanları oluşturmaktadır. Karadeniz Teknik Üniversitesi'nde 2020 Ocak ayında aktif olarak hizmet sunan 2156 öğretim elemanı bulunmaktadır. Örnekleme yöntemine başvurulmadan tüm evrene ulaşılmaya çalışılmıştır. Ancak, öğretim elemanlarının iş yoğunluğu nedeniyle araştırmaya gönüllü katılan öğretim elemanı sayısı 420 ile sınırlı kalmıştır. Araştırma verisi, 21/01/2020 ile 16/03/2020 tarihleri arasında toplanmıştır.

Ayrıca, araştırma evrenini temsil edebilecek örneklem büyüklüğüne ulaşılıp ulaşılmadığını tespit etmek için hesaplama yapılmıştır. Araştırma evreninin tam olarak bilindiği durumlarda, bu evreni temsil eden örneklem sayısını bulabilmek için aşağıdaki formülden faydalanılır (Naing vd., 2006: 9-14):

$$
n=\frac{N \cdot\left(t^{2}\right) \cdot(p \cdot q)}{d^{2} \cdot(N-1)+\left(d^{2}\right) \cdot(p \cdot q)}
$$

Bu formülde,

$\mathrm{n}=$ Örnekleme alınacak birey sayısını

$\mathrm{N}=$ Evrendeki kişi sayısını

$\mathrm{t}=$ Kabul edilen anlamlılık düzeyinde, $\mathrm{t}$ tablosuna göre bulunan teorik değerini

$\mathrm{p}=$ İncelenen olayın görülme sıklığını

$\mathrm{q}=$ İncelenen olayın görülmeme sıklığını

$\mathrm{d}=$ Araştırmacı tarafından kabul edilen örnekleme hatası göstermektedir. 
Araştırma evrenindeki kişi sayısının 2156 olduğu bilinmektedir. Örneklemin çok homojen olmadığı, birbirinden farklılık gösterdiği durumlarda incelenen olayın görülme sıklığı 0,50 ve incelenen olayın görülmeme sıklı̆̆ı 0,50 değerlerini almaktadır. Yapılan bu çalışmada \%95 güven düzeyi ve \%5 kabul edilen örnekleme hatası dikkate alındığında örnekleme alınması yeterli olacak birey sayısı şu şekilde hesaplanır:

$$
n=\frac{2156 \cdot\left(1,96^{2}\right) \cdot(0,50 \cdot 0,50)}{\left(0,05^{2}\right) \cdot(2156-1)+\left(0,05^{2}\right) \cdot(0,50 \cdot 0,50)}=\frac{2070}{5,39}=384
$$

Araştırma evrenini temsil edebilmesi için ulaşılması gereken örneklem büyüklüğü yapılan hesaplama ile minimum 384 olarak belirlenmiş ve veri toplama işlemi istenilen örneklem büyüklüğüne ulaşıldığından sonlandırılmıştır. Öğretim elemanları tarafından yüz yüze görüşme tekniği ile doldurulan 420 anketin tamamı analize dahil edilmiştir.

\subsection{Araştırmanın Yöntemi ve Veri Toplama Aracı}

Araştırmada veri toplama tekniği olarak anket yöntemi uygulanmıştır. Hazırlanan anket 2 bölümden oluşmaktadır. Anketin ilk bölümünde öğretim elemanlarına ilişkin demografik bilgilerin bulunduğu toplam 8 soru yer almaktadır. Anketin ikinci bölümünde ise TSS'nin sürdürülebilirliğini ölçmeye yönelik Tapan (2008) tarafından geliştirilen ve geçerlilik güvenilirlik çalışması yapılan 5'li likert tipine uygun olarak hazırlanan 15 sorunun yer aldığı bir ölçek kullanılmıştır. Likert ölçeğinde cevap seçenekleri “Tamamen Katılıyorum”, "Katılıyorum”, “Kararsızım”, “Katılmıyorum” ve “Tamamen Katılmiyorum" şeklinde ifade edilmiştir.

Araştırmada kullanılan ölçeğin Cronbach a değeri 0.92 olarak hesaplanmıştır ve ölçeğin yüksek derecede güvenilir olduğu sonucuna ulaşılmıştır. Çalışmada verilerin normal dağılıp dağılmadıklarını tespit etmek amacıyla verilerin skewness ve kurtosis değerleri hesaplanmıştır. Hair vd. (2014)'nın savunduğu görüşe göre, verilerin normal dağılım gösterebilmesi için skewness ve kurtosis değerlerinin -1 ile +1 arasında değer almaları gerekmektedir. Yapılan analiz sonucunda, Skewness ve Kurtosis değerleri -1 ile +1 arasında değer aldığından verilerin normal bir dağılım gösterdiği belirlenmiştir (Tablo 1).

TSS'nin sürdürülebilirliği ile sosyo-demografik değişkenler arasındaki ilişki veriler normal dağılım özelliği gösterdiği için parametrik testlerden (Anova ve t testi) yararlanılarak incelenmiştir.

Tablo 1. Araştırma Ölçeğinin Eğrilik ve Basıklık Değer Tablosu

\begin{tabular}{ccc}
\hline Ölçek & Skewness (Eğrilik) & Kurtosis (Basıklık) \\
\hline TSS Sürdürülebilirlik Ölçeği & $-0,188$ & $-0,147$
\end{tabular}

\section{Bulgular}

Bu bölümde ilk olarak anket çalışmasına katılan öğretim elemanlarının demografik özelliklerine ilişkin bilgiler sunulmuştur. Daha sonra, öğretim elemanlarının TSS sürdürülebilirlik ölçeğine verdiği cevaplara ilişkin sonuçlar yüzde olarak gösterilmiş. Son olarak TSS sürdürülebilirlik ölçeği ile sosyo-demografik değişkenler arasındaki ilişki analiz edilmiş ve sonuçlar tablolaştırılarak aktarılmıştır.

Araştırmaya gönüllü katılan öğretim elemanlarının özelliklerine dair frekans ve yüzde değerleri Tablo 2' de sunulmuştur.

Tablo 2. Katılımcıların Sosyo-Demografik Özellikleri

\begin{tabular}{llcc}
\hline Özellik & & Frekans & Yüzde (\%) \\
\hline Fakülteler & İktisadi ve İdari Bilimler Fakültesi & 83 & 19,80 \\
& Edebiyat Fakültesi & 29 & 6,90 \\
& Fen Fakültesi & 30 & 7,10 \\
& Orman Fakültesi & 27 & 6,40 \\
& Mimarlık Fakültesi & 34 & 8,10 \\
& Mühendislik Fakültesi & 110 & 26,10 \\
& Tip Fakültesi & 30 & 7,10
\end{tabular}




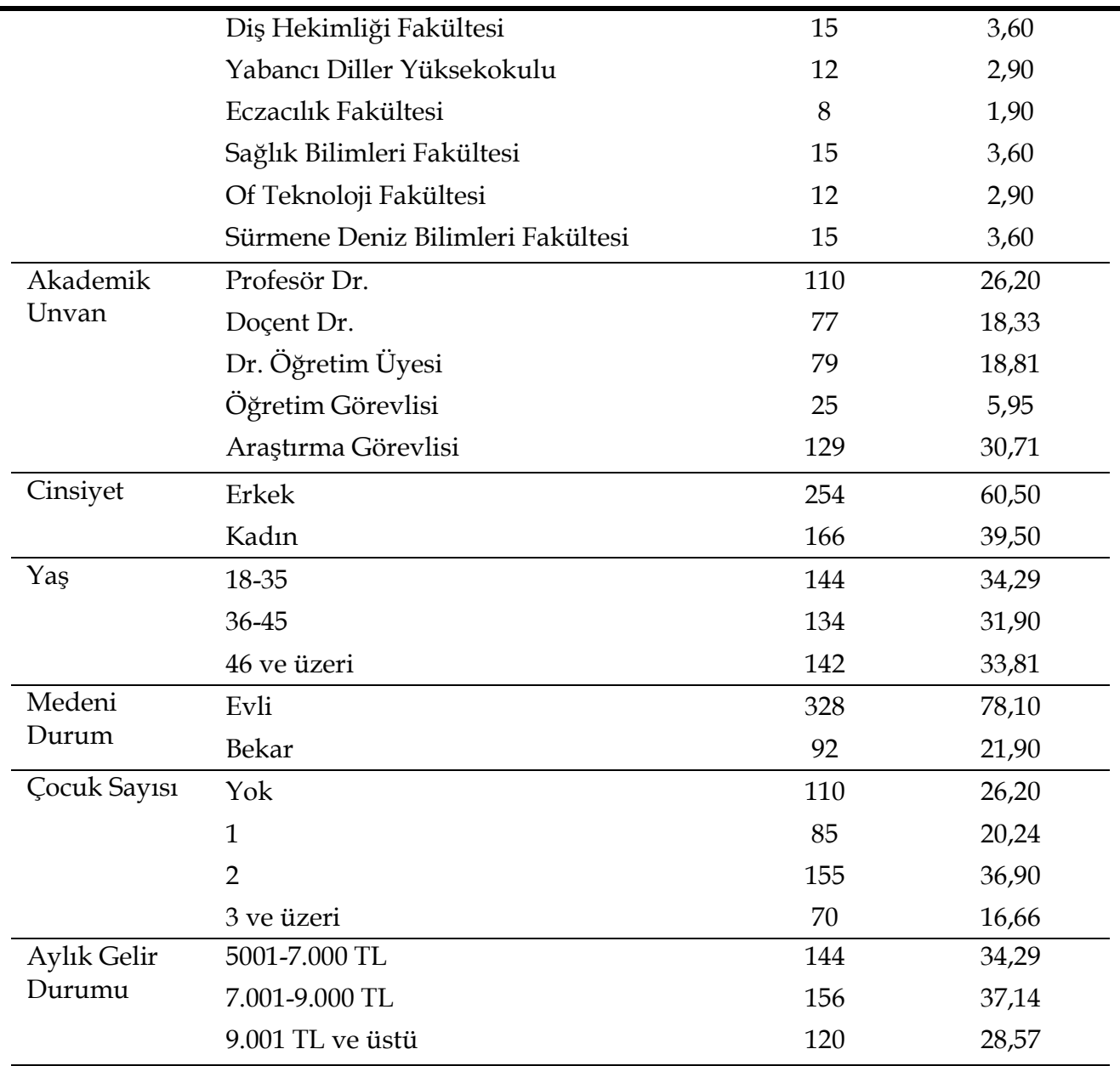

Araştırmaya katılan 420 öğretim elemanının \%60,50'lik kısmını 254 kişiyle erkekler, \%39,50'lik kısmını ise 166 kişiyle kadınlar oluşturmaktadır. Çalışmaya katılan öğretim elemanlarının yaş aralıklarına bakıldığında, en yoğun katılımı \%34,10'luk kısmıyla 25-35 yaş aralığında bulunan öğretim elemanları oluşturmaktadır. Bu gruptan sonraki en yoğun katılım \%31,90'l1k pay ile 36-45 yaş aralığındaki öğretim elemanlarıdır. Medeni durumlarına bakıldığında, öğretim elemanlarının \%78,10'unun evli olduğu gözlenmektedir. Çocuk sayılarına ilişkin elde edilen verilerde ise, 2 çocuğa sahip öğretim elemanları araştırmanın \%37'sini oluşturmaktadır. Bu grubu takip eden en yüksek pay ise \%26,20'lik oranla çocuk sahibi olmayan öğretim elemanlarıdır. Çalışmada önemli bir parametre de akademik unvandır. Çalışmaya katılan 420 öğretim elemanı içerisinde en yoğun katılım araştırma görevlileri nezdinde gerçekleşmiştir. Araştırma görevlileri araştırmanın \%30,70’lik kısmını oluşturmaktadır. Bu gruptan sonra en yoğun katılım profesörler tarafından gerçekleşmiştir. Profesörler çalışmanın \%26,20’lik kısmını oluşturmaktadır. Öğretim elemanlarının aylık gelir durumlarına bakıldığında, en yüksek payı 6.000-7.000 TL arasında geliri bulunan \%33,10'luk kısmıla 139 öğretim elemanı oluşturmaktadır. Bu oranı \%28,50'lik payla $9.001 \mathrm{TL}$ ve üzeri kazancı olan 120 öğretim elemanı takip etmektedir. Araştırmaya katılım oranı en yüksek olan fakülteler, \%26,10’luk payla Mühendislik Fakültesi ve \%19,80'lik payla İktisadi ve İdari Bilimler Fakültesi olmuştur.

Grafik 1'de öğretim elemanlarının TSS'den haberdar olma durumu ve Grafik 2' de ise öğretim elemanlarının TSS'ye sahip olma durumu gösterilmiştir. 


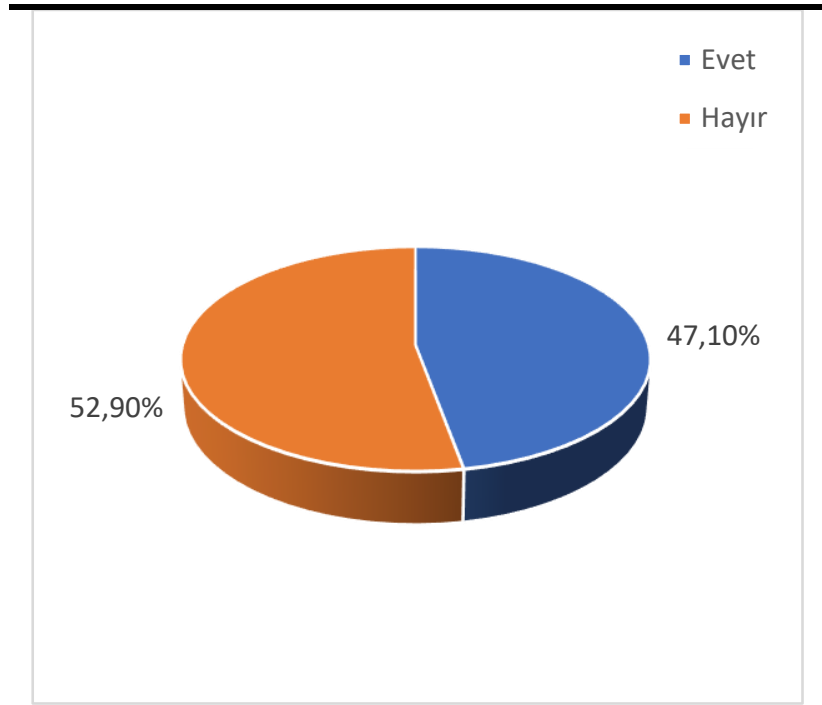

\section{Grafik 1. Öğretim Elemanlarının TSS'den Haberdar Olma Durumları}

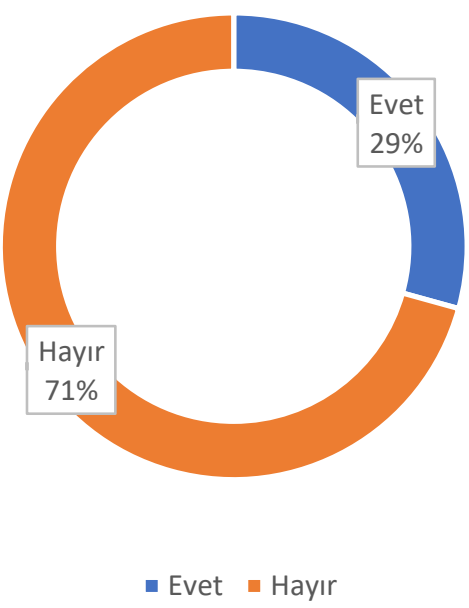
Grafik 2. Öğretim Elemanlarının TSS'ye
Sahip Olma Durumları

Öğretim elemanlarının \%47,10'unun TSS'den haberdar olduğu ve sadece \%29,30'unun bu sigortaya sahip oldukları tespit edilmiştir.

Tablo 3'te öğretim elemanlarının TSS sürdürülebilirlik ölçeğine verdikleri cevapların ortalaması ve standart sapma değerleri sunulmuştur.

Tablo 3'e bakıldığında TSS' nin Sürdürülebilirliği ölçeğinden alınan ortalama puan 2,83 ve standart sapma değeri 0,59 olarak hesaplanmıştır. Bu durum, öğretim elemanlarının TSS'nin sürdürülebilirliği konusunda kararsız bir tutuma sahip olduklarını göstermektedir.

Tablo 3. Öğretim Elemanlarının TSS Sürdürülebilirlik Ölçeğine Yönelik Verdikleri Cevaplara İlişkin Ortalama ve Standart Sapma Değerleri

\begin{tabular}{|c|c|c|c|}
\hline NO & İFADELER & $\begin{array}{c}\bar{x} \\
(\mathrm{ORT})\end{array}$ & S.S. \\
\hline 1 & $\begin{array}{l}\text { GSS, mevcut haliyle Türkiye'nin sağlık hizmetlerinin finansman sorununu } \\
\text { çözebilir. }\end{array}$ & 3,02 & 1,06 \\
\hline 2 & GSS, tek başına topluma eşit ve kaliteli sağlık hizmeti sunmaya yeterlidir. & 2,74 & 1,04 \\
\hline 3 & GSS'nin sunduğu Temel Teminat Paketi'nin kapsamı yeterlidir. & 3,00 & 1,09 \\
\hline 4 & GSS, TSS bileşeni ile birlikte sunulmalıdır. & 2,74 & 0,73 \\
\hline 5 & TSS bileşenli bir GSS toplumun sağlık hizmeti ihtiyacını en iyi şekilde karşılar. & 2,96 & 0,76 \\
\hline 6 & TSS, prim gelirlerinin arttırılması konusunda GSS'ye katkı sağlayacaktır. & 2,74 & 0,75 \\
\hline 7 & TSS, GSS'nin Temel Teminat Paketini kapsam olarak rahatlatacaktır. & 2,39 & 0,73 \\
\hline 8 & TSS, GSS'nin fiyat tarifesini düşürerek, devleti finansal açıdan rahatlatacaktır. & 2,99 & 0,90 \\
\hline 9 & $\begin{array}{l}\text { TSS, devletin tedavi harcamalarının yükünü azaltacak, koruyucu sağlık } \\
\text { hizmetlerinin etkinliğini arttıracaktır. }\end{array}$ & 2,60 & 0,85 \\
\hline 10 & TSS, GSS'nin mali riskini paylaşacaktır. & 2,89 & 0,77 \\
\hline 11 & $\begin{array}{l}\text { TSS bileşenli GSS sisteminde kamu ve özel sektör arasında çift kademeli bir denetim } \\
\text { mekanizması oluşacaktır. }\end{array}$ & 2,38 & 0,82 \\
\hline 12 & TSS ile fiyat yönünden oluşan baskı azalarak sağlık hizmetlerinin kalitesi artacaktır. & 2,97 & 0,89 \\
\hline 13 & TSS'nin uygulanabilirliği için yasal altyapı yeterlidir. & 3,05 & 0,58 \\
\hline 14 & Özel sigorta şirketleri TSS konusunda yeterli deneyime sahip değildir. & 3,08 & 0,86 \\
\hline 15 & TSS bileşenli GSS, sağlık hizmetlerinin finansman sorununu çözecektir. & 2,91 & 0,72 \\
\hline $1-15$ & TSS SÜRDÜRÜLEBİLİRLİK ÖLÇEĞİ & 2,83 & 0,59 \\
\hline
\end{tabular}


Tablo 4'te öğretim elemanlarının TSS'nin sürdürülebilirliği konusundaki görüşlerinde sosyodemografik değişkenlere (cinsiyet, medeni durum, yaş, çocuk sayısı, görev yapılan bilim dalı, akademik unvan ve aylık gelir düzeyi) göre oluşan farklılığın anlamlı olup olmadığına dair test istatistikleri sunulmuştur.

Analiz sonuçlarına göre, TSS’nin sürdürülebilirliği konusunda öğretim elemanları arasında cinsiyet değişkenine bağlı olarak \%5 düzeyinde, medeni durum değişkenine göre \%1 düzeyinde anlamlı bir farklılık oluştuğu tespit edilmiştir. Erkek öğretim elemanlarının ölçek puanının kadınlardan ve bekar öğretim elemanlarının ölçek puanının evli olanlardan daha yüksek olduğu belirlenmiştir. "TSS'nin sürdürülebilirliği açısından öğretim elemanları arasında cinsiyet bakımından fark vardır" ve "TSS'nin sürdürülebilirliği açısından öğretim elemanları arasında medeni durum bakımından fark vardır" hipotezleri kabul edilmiştir.

Elde edilen veriler sonucunda 18-35 yaş aralığında bulunan katılımcıların ölçek ortalamaları 2,88, 36-45 yaş aralığında bulunan katılımcıların ölçek ortalamaları 2,85 ve 46 yaş ve üzerindeki katılımcıların ölçek ortalamaları 2,76 olarak hesaplanmıştır. Ancak, ANOVA testi sonucunda belirlenen yaş grupları arasında oluşan farklılığın $\% 5$ düzeyinde anlamlı olmadığı bulunmuştur. Dolayısıyla, “TSS'nin sürdürülebilirliği açısından öğretim elemanları arasında yaş bakımından fark vardır." hipotezi reddedilmiştir.

Tablo 4. Sosyo-Demografik Değişkenlere Göre TSS'nin Sürdürülebilirliği ile İlgili Anova ve T Testi Analiz Sonuçları

\begin{tabular}{|c|c|c|c|c|c|c|}
\hline Değişken & Gruplar & $N$ & Ortalama $(x)$ & SS & F veya $t$ & $p$ \\
\hline \multirow{3}{*}{$\begin{array}{l}\text { Görev Yapılan } \\
\text { Bilim Dalı }\end{array}$} & Sosyal Bilimler & 124 & 2,72 & 0,436 & \multirow{3}{*}{3,349} & \multirow{3}{*}{0,036} \\
\hline & Fen Bilimleri & 228 & 2,89 & 0,639 & & \\
\hline & Sağlık Bilimleri & 68 & 2,82 & 0,624 & & \\
\hline \multirow{5}{*}{$\begin{array}{l}\text { Akademik } \\
\text { Unvanlar }\end{array}$} & Araştırma Görevlisi & 129 & 2,88 & 0,543 & \multirow{5}{*}{1,242} & \multirow{5}{*}{0,292} \\
\hline & Öğretim Görevlisi & 25 & 2,85 & 0,584 & & \\
\hline & Doktor Öğretim Üyesi & 79 & 2,90 & 0,552 & & \\
\hline & Doçent Doktor & 77 & 2,77 & 0,673 & & \\
\hline & Profesör Doktor & 110 & 2,75 & 0,596 & & \\
\hline \multirow[t]{2}{*}{ Cinsiyet } & Erkek & 254 & 2,88 & 0,546 & \multirow[t]{2}{*}{2,320} & \multirow[t]{2}{*}{0,021} \\
\hline & Kadın & 166 & 2,74 & 0,639 & & \\
\hline \multirow{2}{*}{$\begin{array}{l}\text { Medeni } \\
\text { Durum }\end{array}$} & Evli & 328 & 2,79 & 0,616 & \multirow{2}{*}{$-2,847$} & \multirow{2}{*}{0,005} \\
\hline & Bekar & 92 & 2,96 & 0,452 & & \\
\hline \multirow{3}{*}{ Yaş Aralıkları } & $18-35$ & 144 & 2,88 & 0,525 & \multirow{3}{*}{1,708} & \multirow{3}{*}{0,182} \\
\hline & $36-45$ & 134 & 2,85 & 0,597 & & \\
\hline & 46 ve üzeri & 142 & 2,76 & 0,633 & & \\
\hline \multirow{4}{*}{ Çocuk Sayısı } & Çocuksuz & 110 & 2,91 & 0,444 & \multirow{4}{*}{2,255} & \multirow{4}{*}{0,081} \\
\hline & 1 & 85 & 2,84 & 0,539 & & \\
\hline & 2 & 155 & 2,74 & 0,675 & & \\
\hline & 3 ve üzeri & 70 & 2,89 & 0,617 & & \\
\hline \multirow{3}{*}{$\begin{array}{l}\text { Aylık gelir } \\
\text { durumu }\end{array}$} & $5.000-7.000 \mathrm{TL}$ & 144 & 2,88 & 0,531 & \multirow{3}{*}{4,254} & \multirow{3}{*}{0,015} \\
\hline & 7.001-9.000 TL & 156 & 2,88 & 0,628 & & \\
\hline & 9.001 TL ve üzeri & 120 & 2,70 & 0,582 & & \\
\hline
\end{tabular}

Çocuk sayısına göre TSS' nin sürdürülebilirliği konusunda, öğretim elemanları arasında anlamlı bir farklılığın olup olmadığını belirlemek için yapılan ANOVA analizi sonucunda, elde edilen anlamlılık değeri 0,081 olarak belirlenmiştir. Bu değer, çocuk sayısına göre öğretim elemanları arasında \%5 düzeyinde anlamlı bir farklılık oluşmadığını göstermektedir. Yani, “TSS'nin 
sürdürülebilirliği açısından öğretim elemanları arasında çocuk sayısı bakımından fark vardır." hipotezi reddedilmiştir.

Akademik unvana göre yapılan analiz sonucunda, araştırma görevlisi için ölçek ortalaması 2,88, öğretim görevlisi için 2,85, doktor öğretim üyesi için 2,90, doçent doktor için 2,77 ve profesör doktor için ise 2,75 olarak hesaplanmıştır. Analizi sonucunda elde edilen anlamlılık değeri 0,292 olup, bu değer 0,05' ten yüksek olduğu için gruplar arasında anlamlı derecede önemli bir farkın bulunmadı̆̆ı tespit edilmiştir. Dolayısıyla, “TSS'nin sürdürülebilirliği açısından öğretim elemanları arasında akademik unvan bakımından fark vardır." hipotezi reddedilmiştir.

TSS'nin sürdürülebilirliği ölçeğinden alınan ortalama puanın, sosyal bilimler alanında çalışan öğretim elemanları için 2,72, fen bilimleri alanında çalışanlar için 2,89 ve sağlık bilimleri alanında çalışanlar için ise 2,82 olduğu hesaplanmıştır. Analizi sonucunda, gruplar arasında oluşan bu farklılığın \%5 düzeyinde anlamlı olduğu belirlenmiştir. Bu farkın hangi gruplar arasında olduğunu tespit etmek için post-hoc testlerinden yararlanılmıştır. Öğretim elemanlarının çalıştıkları bilim dalı ile TSS'nin Sürdürülebilirliği ölçeği arasında homojenlik değeri $\% 5$ ten küçük hesaplandığ1 için Games-Howell Post Hoc analizi uygulanmıştır. Analiz sonucuna göre, sosyal bilimler ile fen bilimleri arasında anlamlı derecede önemli bir farkın bulunduğu görülmektedir. Fen bilimleri alanında çalışan öğretim elemanlarının sosyal bilimlerde çalışanlara nazaran TSS'nin sürdürülebilirliğine daha fazla inandığı ve bu sigortadan daha fazla yararlandıkları tespit edilmiştir. Aralarındaki ortalama farkı 0,168 ve anlamlılık düzeyi \% 5'in altındadır. Sosyal bilimler ile sağlık bilimleri arasında ise anlamlı derecede önemli bir fark bulunmamaktadır. Ayrıca, sağlık bilimlerinde görev yapan öğretim elemanları ile de fen ve sosyal bilim dallarında görev yapanlar arasında anlamlı bir fark bulunmamaktadır. Dolayısıyla, “TSS'nin sürdürülebilirliği açısından öğretim elemanları arasında görev yapılan fakülte bakımından fark vardır.

Elde edilen veriler sonucunda, aylık gelir durumu 5.000-7.000 TL aralığında bulunan toplam 144 öğretim elemanının ölçek ortalaması 2,88, 7.001-9.000 TL aralığında bulunan toplam 156 öğretim elemanının ölçek ortalaması 2,88 ve 9.001 TL ve üzeri geliri bulunan toplam 120 öğretim elemanının ölçek ortalaması 2,70 olarak hesaplanmıştır. Yapılan ANOVA test sonucunda anlamlılık değeri 0,015 olarak elde edilmiştir. Bu değer 0,05'ten küçük olduğu için gruplar arasında anlamlı derecede önemli bir farkın olduğu tespit edilmiştir. Aylık gelir durumu ile ölçek arasında homojenlik değeri 0,05'ten büyük olduğu için Tukey Post Hoc analizi uygulanmıştır. Tukey Post Hoc analiz sonucuna göre, 9.001 TL ve üzeri gelire sahip olan öğretim elemanları ile 5.000-7.000 TL aralığında gelire sahip öğretim elemanları arasında anlamlı derecede bir fark bulunmaktadır. Bu iki grup arasında ortalama fark 0,185 ve anlamlılık düzeyi 0,05 'in altındadır. Aynı şekilde 9.001 TL ve üzeri gelire sahip olan öğretim elemanları ile 7.001-9.000 TL aralığında gelire sahip öğretim elemanları arasında da anlamlı derecede bir fark bulunmaktadır. Bu iki grup arasında ortalama fark 0,182 ve anlamlılık düzeyi 0,05'in altındadır. 9001 TL ve üzeri gelire sahip öğretim elemanları diğer iki gruba nazaran TSS yaptırma dereceleri yüksek ve bu sigortanın sürdürülebilirliğine ilişkin görüşleri diğerlerine nazaran daha olumludur. 5000-7000 TL ile 7001-9000 TL gelir aralığına sahip öğretim elemanları arasında ise anlamlı derecede önemli bir fark bulunmamaktadır. Bu bilgiler ışı̆̆ında, “TSS'nin sürdürülebilirliği açısından öğretim elemanları arasında aylık gelir durumu bakımından fark vardır." hipotezi kabul edilmiştir.

Tablo 5'te sosyo-demografik değişkenlere göre TSS'nin sürdürülebilirliği ile ilgili hipotez sonuçları sunulmuştur.

Tablo 5. Sosyo-Demografik Değişkenlere Göre TSS’nin Sürdürülebilirliği ile İlgili Hipotez Sonuçları

\begin{tabular}{ccc}
\hline Hipotez & Hipotez İçeriği & Kabul/Ret \\
\hline $\mathrm{H}_{1}$ & TSS'nin sürdürülebilirliği açısından ögretim elemanları arasında & Kabul \\
cinsiyet bakımından fark vardır. & Ret \\
\hline $\mathrm{H}_{2}$ & $\begin{array}{c}\text { TSS'nin sürdürülebilirliği açısından öğretim elemanları arasında yaş } \\
\text { bakımından fark vardır. }\end{array}$ & Kabul \\
\hline $\mathrm{H}_{3}$ & $\begin{array}{c}\text { TSS' nin sürdürülebilirliği açısından öğretim elemanları arasında } \\
\text { medeni durum bakımından fark vardır. }\end{array}$ & \\
\hline
\end{tabular}




\begin{tabular}{ccc}
$\mathrm{H}_{4}$ & TSS'nin sürdürülebilirliği açısından öğretim elemanları arasında & Ŗocuk sayısı bakımından fark vardır. \\
\hline $\mathrm{H}_{5}$ & $\begin{array}{c}\text { TSS' nin sürdürülebilirliği açısından öğretim elemanları arasında } \\
\text { akademik unvan bakımından fark vardır. }\end{array}$ & Ret \\
\hline $\mathrm{H}_{6}$ & $\begin{array}{c}\text { TSS'nin sürdürülebilirliği açısından öğretim elemanları arasında } \\
\text { bilim dalları bakımından fark vardır. }\end{array}$ & Kabul \\
\hline $\mathrm{H}_{7}$ & $\begin{array}{c}\text { TSS'nin sürdürülebilirliği açısından öğretim elemanları arasında } \\
\text { aylık gelir durumu bakımından fark vardır. }\end{array}$ & Kabul \\
\hline
\end{tabular}

\section{Sonuç ve Değerlendirme}

$\mathrm{Bu}$ çalışmada, Karadeniz Teknik Üniversitesi'ndeki öğretim elemanlarının TSS'nin sürdürülebilirliği hakkındaki görüşleri sosyo-demografik değişkenlere göre incelenmiştir. Çalışma kapsamında Karadeniz Teknik Üniversitesi'nde bulunan ve araştırmaya gönüllü katılan toplam 420 öğretim elemanına yüz yüze anket uygulanmıştır. Araştırmada cinsiyet, medeni durum, yaş, çocuk sayısı, bilim dalı, akademik unvan ve aylık gelir gelir düzeyi değişkenleri ile TSS'nin sürdürülebilirliği ile ilgili görüşleri arasındaki ilişkiyi incelemek için yedi hipotez önerilmiş ve bu hipotezler parametrik testlerden (ANOVA ve $t$ testi) yararlanılarak test edilmiştir.

TSS'nin sürdürülebilirliği ölçeğinden öğretim elemanlarının aldığ standart sapma değeri ise 0,59 olarak hesaplanmıştır. Bu durum, öğretim elemanlarının TSS'nin sürdürülebilirliği konusunda kararsız olduklarını göstermektedir.

TSS' nin sürdürülebilirlik düzeyi ile cinsiyet, medeni durum, bilim dalları ve aylık gelir düzeyi değişkenleri arasında \%5 düzeyinde anlamlı bir ilişki olduğu belirlenmiştir. TSS'nin sürdürülebilirliği konusunda erkeklerin kadınlara göre, bekar öğretim elemanlarının evli olanlara göre ve fen bilimleri alanında görev yapan öğretim elemanlarının sosyal bilimlerdekilere göre daha olumlu bir görüşe sahip olduğu tespit edilmiştir. Aylık gelir düzeyine göre ise 5000-7000 ile 70019000 TL gelire sahip öğretim elemanlarının 9001 ve üzeri gelire sahip olanlara göre TSS'nin sürdürülebilirliğine ilişkin görüşlerinin daha olumlu olduğu bulunmuştur. Ancak, sosyodemografik değişkenlerden akademik unvan, yaş ve çocuk sayısı değişkenlerine göre TSS'nin sürdürülebilirliği konusunda gruplar arasında oluşan farklılığın istatistiksel olarak anlamlı olmadığ1 tespit edilmiştir.

Bilgi ve eğitim düzeyi yüksek, toplumda önemli bir konuma sahip olan öğretim elemanlarının TSS'nin sürdürülebilirliği konusunda kararsız olması, Genel Sağlık Sigortası kapsamında sunulan hizmetlerinin çerçevesi genişletmek amacıyla sunulan bu sigortanın yeterince tanıtılmadığını ve öğretim elemanlarının bu konuda yeterince bilgiye sahip olamadıklarını göstermektedir.

TSS'nin tanınırlık düzeyinin artırılması, bireylerin sigortacılığa karşı sahip olduğu olumsuz bakış açısının önlenebilmesi ve hem genel sağlık sigortasının hem de sunulan hizmetlerin kapsamında yaşanan karmaşıklıkların giderilebilmesi için ilgili kurumlarca tanıtıcı ve bilgilendirici faaliyetlerin yapılması önerilmektedir.

Araştırma sonuçlarının sigorta şirketlerinin TSS ürünü üzerinde çalışmalarını geliştirmesi, ürün çeşitlendirmesi yapması, tanıtım faaliyetlerini artırması konusunda yol gösterici olması ve ayrıca ulusal ve uluslararası literatüre yeni veriler sunması, bu alanda yeni çalışmalar yapılmasını teşvik etmesi bakımından önemli katkılar sunması beklenmektedir.

\section{Araştırmanın Kısıtlılı̆̆ı}

Zaman ve maliyet kısıtından dolayı araştırma sadece Karadeniz Teknik Üniversitesi'nde görev yapan öğretim elemanları ile gerçekleştirilmiştir. Araştırmada tüm evrene ulaşılması hedeflenmiş ancak öğretim elemanlarının iş yoğunluğundan dolayı araştırmaya katılan gönüllü sayısı 420 kişi ile sınırlı kalmıştır. Araştırma verisi, yalnızca Karadeniz Teknik Üniversitesi'ndeki öğretim elemanlarından toplandığı için, sonuçların tüm öğretim elemanları için genellenememesi bu araştırmanın bir diğer kısıdını oluşturmaktadır. Bu nedenle, tüm üniversitelerdeki öğretim elemanlarını kapsayacak şekilde yeni araştırmaların planlanması önerilmektedir. 


\section{Kaynakça}

Bauer, J. M. vd. (2019). Selection Behaviour in The Market For Private Complementary Long-Term Care Insurance in Germany. Available at SSRN, 1-42. https:/ / ssrn.com/abstract=2995424

Biro, A. \& Hellowell, M. (2016). Public Private Sector Interactions And The Demand For Supplementary Health Insurance In The United Kingdom. Health Policy, 120(7), 840-847.

Bitimli, G. (2019). Türkiye'de TSS ve Müşterilerinin Profili Üzerine Bir Araştırma, Yayınlanmamış Yüksek Lisans Tezi, Marmara Üniversitesi - Bankacılık ve Sigortacılık Enstitüsü, İstanbul.

Cihangiroğlu, M. (2019). Tamamlayıcı Sağlık Sigortalarının Sağlık Sigortacılığına ve Sağlık Sistemine Etkileri: Türkiye Örneği, Yayınlanmamış Yüksek Lisans Tezi, Marmara Üniversitesi - Bankacılık ve Sigortac1lı Enstitüsü, İstanbul.

Costa, J., \& Rovira, J. (2005). Why Some People Go Private and Others Do Not: Supplementary Health Insurance in Spain. Public Finance \& Management, 5(4), 523-542.

Değer, C.C. vd. (2013). Supplementary Health Insurance in Turkey. Value in Health, 16(7), A454.

Hair, Joseph F. vd. (2014). Multivariate Data Analysis. 7.Bask1. Pearson New International Edition, Edinburgh Gate.

Holst, L. vd. (2018). Role of Supplementary Health Insurance in Switching Behaviour of Consumers in the Netherlands. European Journal of Public Health, 28(4), 213-249.

Kang, S. vd. (2009). Effects of Supplementary Private Health Insurance on Physician Visits in Korea. Journal of the Formosan Medical Association. 108(12), 912-920.

Kaplan, G. vd. (2017). Supplementary Health Insurance From The Consumer Point Of View: Are Israelis Consumers Doing An Informed Rational Choice When Purchasing Supplementary Health Insurance?. Health Policy. 121(6), 708-714.

Mossialos, E. \& Djordjevic, A. (2017). International Profiles of Health Care Systems. London School of Economics and Political Science. 1, 110-121.

Naing, L. vd. (2006). Practical Issues in Calculating the Sample Size for Prevalence Studies. Archives of Orofacial Sciences. 1, 9-14.

Orhan, E. \& Kıyak, M. (2015). Özel Hastanelerde TSS'nin İşleyişi ve Sorunları. Research Journal of Business and Management. 2(3), 308-321.

Önder, M. E. vd. (2016). Sağlıkta Yeni Bir Finansman Yöntemi Olan Tamamlayıcı ve Destekleyici Sağlık Sigortası Hakkında Hastaların Bilgi ve Memnuniyet Düzeyleri Üzerine Bir Araştırma. Uluslararası İşletme, Ekonomi ve Yönetim Perspektifleri Dergisi. 1(1), 23-36.

Pierre, A., \& Jusot, F. (2017). The Likely Effects Of Employer-Mandated Complementary Health Insurance On Health Coverage In France. Health Policy. 121(3), 321-328.

Rad, E. H. vd. (2017). Complementary Health Insurance, Out-Of-Pocket Expenditures, and Health Services Utilization: A Population Based Survey. Medical Journal of the Islamic Republic of Iran. 31(59), 1-5.

Saliba, B. \& Ventelou, B. (2007). Complementary Health Insurance in France Who Pays? Why? Who Will Suffer From Public Disengagement?. Health Policy. 81(2-3), 166-182.

SGK (2012), Tamamlayıcı veya Destekleyici Sağlık Sigortası Uygulamaları, SGK Yayınları, Ankara.

Stevens, Y. vd. (1998). Issues in Complementary Health Insurance in Belgium. International Social Security Review. 51(4), 71-89.

Şahin, H. (2018), Sağlık Finansmanında TSS'nin Rolü ve Uygulanabilirliği, Yayınlanmamış Yüksek Lisans Tezi, Beykent Üniversitesi - Sosyal Bilimler Enstitüsü.

Şahin, H. (2018). Sağlık Finansmanında TSS'nin Rolü ve Uygulanabilirliği. Yayınlanmamış Yüksek Lisans Tezi, Beykent Üniversitesi - Sosyal Bilimler Enstitüsü, İstanbul.

Tajika, E. \& Kikuchi, J. (2012). The Roles of Public and Private Insurance for The Healhcare Reform of Japan. Public Policy Review. 8(2), 123-144.

Tapan, B. (2008). Genel Sağlık Sigortası'nın Sürdürülebilirliği için TSS'nın Gerekliliği. Yayınlanmamış Doktora Tezi, Kadir Has Üniversitesi - Sosyal Bilimler Enstitüsü, İstanbul.

Tapan, B. vd. (2015). Özel Sigorta Şirketlerinin Genel Sağllk Sigortasının Sürdürülebilirliği İçin TSS'nin Gerekliliği Konusundaki Görüşlerinin Değerlendirilmesi. FNG \& Bilim Tıp Dergisi. 1(2), 77-86. 
Thomson, S. \& Mossialos, E. (2004). Voluntary Health Insurance In The European Union. World Health Organization. Copenhagen

TSB (2019). Türkiye Sigortalar Birliği TSS İstatistikler. https://www.tsb.org.tr/resmiistatistikler.aspx?pageID=909. (30.12.2019)

Valtonen, H. vd. (2014). Supplementary Health Insurance in Finland: Consumer Preferences and Behaviour. The Social Insurance Institution, 9-32.

\section{Extended Abstract}

\section{Aim and Scope}

The aim of this study is to determine the views of the lecturers on the sustainability of complementary health insurance (SHI) and to examine the relationship between socio-demographic characteristics and their views on the sustainability of complementary health insurance. In this context, a face-to-face questionnaire was applied to a total of 420 lecturers who work at Karadeniz Technical University and participated in the study voluntarily.

\section{Methods}

Questionnaire method was used as data collection technique in the research. The prepared questionnaire consists of 2 parts. In the first part of the questionnaire, there are a total of 8 questions including demographic information about lecturers. In the second part of the questionnaire, a scale including 15 questions prepared in accordance with the 5-point likert type developed by Tapan (2008) to measure the sustainability of SHI was used. On the Likert scale, the answer options are expressed as "I totally agree", "I agree", "Undecided", "Disagree" and "Completely Disagree".

The Cronbach a value of the scale used in the study was calculated as 0.92 and it was concluded that the scale was highly reliable. In the study, the skewness and kurtosis values of the data were calculated in order to determine whether the data were distributed normally. Hair et al. (2014), in order for the data to show a normal distribution, the values of skewness and kurtosis should be between -1 and +1 . As a result of the analysis, it was determined that the data showed a normal distribution, as the Skewness and Kurtosis values took values between -1 and +1 .

The relationship between the sustainability of SHI and socio-demographic variables was examined using parametric tests (Anova and $t$ test), since the data showed normal distribution characteristics.

\section{Findings}

420 lecturers participated in the research, $60.50 \%$ of them were men with 254 people, and $39.50 \%$ of them were women with 166 people. Looking at the age ranges of the lecturers participating in the study, the most intensive participation consists of the lecturers between the ages of 25-35 with $34.10 \%$. Looking at their marital status, it is observed that $78.10 \%$ of the lecturers are married. Among the 420 academic staff who participated in the study, the most intensive participation was with the research assistants. Research assistants constitute $30.70 \%$ of the research. When the monthly income of the academic staff is examined, it is 139 academic staff with the highest share of which is between 6.000-7.000 TL and $33.10 \%$.

It was determined that $47.10 \%$ of the lecturers were aware of SHI and only $29.30 \%$ of them had this insurance. The average score obtained from the SHI Sustainability scale was calculated as 2.83 and the standard deviation value as 0.59 . This situation shows that the lecturers have an undecided attitude towards the sustainability of SHI.

According to the results of the analysis, it was determined that there is a significant difference at the level of $5 \%$ depending on the gender variable and at the level of $1 \%$ according to the marital status variable among the instructors on the sustainability of SHI. As a result of the data obtained, the scale averages of the participants between the ages of 18-35 were 2.88, the scale averages of the participants between the ages of 36-45 were 2.85, and the scale averages of the participants aged 46 and over were calculated as 2.76. However, it was found that the difference between the age groups determined as a result of the ANOVA test was not significant at the $5 \%$ level. It has been calculated that the average score obtained from the sustainability scale of SHI is 2.72 for academic staff working in the field of social sciences, 2.89 for those working in the field of science and 2.82 for those working 
in the field of health sciences. As a result of the analysis, it was determined that this difference between the groups was significant at the $5 \%$ level.

\section{Conclusion}

The average score of the lecturers on the sustainability scale of SHI was calculated as 2.83 . This situation shows that the lecturers are undecided about the sustainability of SHI. It has been determined that there is a significant relationship at the level of $5 \%$ between the sustainability level of SHI and the variables of gender, marital status, disciplines and monthly income level. On the sustainability of SHI, it has been determined that males have a more positive view than females, single lecturers compared to married ones, and lecturers in the field of science than social sciences. According to the monthly income level, it was found that the opinions of the lecturers with 5.0007.000 and 7.001-9.000 TL income on the sustainability of SHI were more positive than those with an income of 9.001 and above. However, it was determined that the difference between the groups regarding the sustainability of $\mathrm{SHI}$ according to the variables of academic title, age and number of children among socio-demographic variables was not statistically significant. 